\title{
Analisis Peran Pemuda dalam Pengembangan Koperasi di Kota Kisaran
}

\author{
Supandi \\ Sirojuzilam \\ Agus Suriadi \\ Sekolah Pascasarjana Universitas Sumatera Utara \\ Email: data.supandi@gmail.com
}

\begin{abstract}
The objective of the research was to find out the development of cooperatives in Kisaran. The population was all youngsters who lived in Kisaran. The samples were 96 managers of cooperatives that were not youth and dwelled in two subdistricts: Kisaran Barat Subdistrict and Kisaran Timur Subdistrict according to Franck Lynch formula. The data were analyzed by using descriptive percentage analysis in order to find out the role of youth in the development of cooperatives in Kisaran and Shift Share method in order to find out the role of cooperatives in the development of Kisaran. The primary data were gathered by using questionnaires and secondary data were obtained from the related agencies such as the Cooperative, Industry, and Commerce Agency of Kisaran and Central Bureau of Statistics of Kisaran. The result of the descriptive percentage analysis shows as the Agent of Change, they are obliged to improve cooperatives and it is the thing which is done by youth (64.58\%). As the Agent of Development, they play an active role in development of cooperatives (68.75\%). As the Agent of Modernization, they productively active in marketing cooperatives (68.75\%). Therefore, the role of youth influences the development of cooperatives in Kisaran. The result of Shift Share has Proportional shift (P) of 69.76877 which indicates that sub-sector of cooperatives in Asahan Regency has quicker growth than that in the sectors of industry, electricity, gas and drinking water, transportation and communication, and the other services in Kisaran and has Differential Shift (D) of 77.18951 which indicates that sub-sector of cooperatives in Asahan Regency has relatively higher competitiveness than that of the other sectors..
\end{abstract}

Key words: Cooperative, Shift Share, Role of Youth

\section{PENDAHULUAN}

emuda merupakan unsur yang menarik dan esensial dalam suatu gerakan perubahan, maka menarik untuk dikaji karena di dalam jiwa pemuda terdapat kerelaan berkorban demi cita-cita dan di dalam pemuda terdapat api idealisme yang tidak menuntut QE Journal |Vol.07 - No. 01 M arch 2018 - 56 
balasan, baik berupa uang atau kedudukan. (Widyanto: 2010).

Pemuda adalah sumber daya manusia pembangunan saat ini dan merupakan salah satu komponen penting bangsa ini. Perencanaan pembangunan suatu bangsa sangat tergantung terhadap kader-kader pembangunan itu sendiri. Oleh karena itu kedudukan angkatan muda dalam suatu masyarakat adalah vital bagi masyarakat itu. Apalagi dalam era abad 21 yakni era penuh dengan kompetisi, diperlukan pemuda yang terlatih, inovatif, serta pembaharu untuk meneruskan cita-cita pembangunan.

Menurut Data Badan Pusat Statistik (BPS) menyatakan bahwa dari sekitar 251 juta jiwa penduduk Indonesia saat ini, penduduk usia produktif (15-64 tahun) mendominasi sekitar 44,98\% dari total keseluruhan jumlah penduduk Indonesia saat ini. Proporsi penduduk usia produktif ini diperkirakan akan terus meningkat hingga 2025, dengan bonus demografi tersebut, jumlah penduduk usia produktif mencapai $2 \beta$ dari total jumlah penduduk di Indonesia. Dari $2 \beta$ jumlah penduduk usia produktif tersebut, didalamnya tentu terdapat peran pemuda. Situasi ini tentu dapat mengantarkan Indonesia menjadi bangsa yang lebih besar dan lebih maju dalam berbagai aspek.

Pemuda selain menjadi aset sosial, karena tergolong usia produktif (berdasarkan undang-undang kepemudaan usia pemuda antara 16 sampai 30 tahun), juga merupakan aset dalam bidang ideologi, politik, ekonomi dan budaya serta koperasi. Sebagai aset yang penting dalam koperasi, pemuda seharusnya memiliki andil yang sangat besar dalam pengembangan koperasi. Koperasi adalah soko guru dalam perekonomian nasional, soko guru sama dengan tiang atau penyangga bagi perekonomian sehingga koperasi memiliki peranan yang penting dalam memajukan perekonomian nasional. Apabila koperasi suatu negara baik, maka akan berefek langsung pada pendapatan negara tersebut demikian pula sebaliknya.

Koperasi merupakan salah satu pendorong pertumbuhan ekonomi yang berbasis ekonomi kerakyatan. Koperasi merupakan badan usaha yang dimiliki dan dioperasikan oleh orang-seorang demi kepentingan anggota. Koperasi mempunyai peranan yang sangat penting bagi semua kalangan masyarakat dalam melakukan transaksi keuangan. 
Koperasi secara etimologi berasal dari kata cooperation, terdiri dari kata co yang artinya bersama dan operation yang artinya bekerja atau berusaha. Jadi kata cooperation dapat diartikan bekerja bersama-sama atau usaha bersama untuk kepentingan bersama. Secara umum koperasi dipahami sebagai perkumpulan orang yang secara sukarela mempersatukan diri untuk memperjuangkan peningkatan kesejahteraan ekonomi mereka, melalui pembentukan sebuah perusahaan yang dikelola secara demokratis.

Koperasi adalah suatu perkumpulan yang beranggotakan orang perorang atau badan hukum, yang memeberikan kebebasan kepada anggota untuk masuk dan keluar, dengan bekerjasama secara kekeluargaan menjalankan usaha untuk mempertinggi kesejahteraan jasmaniah para anggotanya (Chaniago dalam Arifin Sitio dan Halomoan Tamba, 2001).

Definisi koperasi di Indonesia termuat dalam UU No. 17 tahun 2012 tentang Perkoperasiaan yang menyebutkan bahwa koperasi adalah badan hukum yang didirikan oleh orang perseorangan atau badan hukum Koperasi, dengan pemisahan kekayaan para anggotanya sebagai modal untuk menjalankan usaha, yang memenuhi aspirasi dan kebutuhan bersama di bidang ekonomi, sosial, dan budaya sesuai dengan nilai dan prinsip Koperasi.

Berdasarkan beberapa pengertian di atas koperasi dapat diartikan sebagai perkumpulan orang atau badan usaha yang memiliki tujuan yang sama yaitu mencapai kesejahteraan ekonomi yang berlandaskan asas kekeluargaan. Koperasi disebut sebagai soko guru perekonomian di Indonesia. Keberadaannya diharapkan mampu menjadi penopang perekonomian.

Dalam rangka pengembangan koperasi sebagai badan usaha pada dasarnya yang perlu mendapat perhatian adalah bagaimana pemilihan sistem kelembagaan yang tepat yang lebih mendukung pengembangan aktivitas ekonomi dengan tujuan adanya keberpihakan kepada kesejahteraan masyarakat secara luas. Dengan kata lain, penekanan akan memperjelas jutifikasi pentingnya keberadaan bentuk badan usaha yang dikelola dari oleh dan untuk masyarakat. Hal ini sangat relevan dengan keberadaan koperasi. Pengembangan aktivitas ekonomi yang sesuai dengan konteks ini adalah aktivitas ekonomi yang juga bertujuan selain untuk meningkatkan nilai tambah sumber daya yang tersedia yang 
dikembangkan dengan pendekatan bisnis, juga aktivitas ekonomi yang berkembang ke arah terjaminnya partisipasi yang tinggi dari masyarakat.

Indonesia telah menjadikan koperasi sebagai salah satu sektor ekonomi penting. Sebagai sektor ekonomi penting, koperasi mendapatkan perhatian serius dari pemerintah, dikeluarkannya Undang-undang Tahun 2012 No 17 tentang perkoperasian adalah sebagai dasar pijakan penyelenggaraan koperasi. Tujuan penyelenggaraan koperasi menurut undang-undang tersebut adalah meningkatkan kesejahteraan Anggota pada khususnya dan masyarakat pada umumnya, sekaligus sebagai bagian yang tidak terpisahkan dari tatanan perekonomian nasional yang demokratis dan berkeadilan.

Berdasarkan data Kementerian Koperasi dan Usaha Kecil dan Menengah (Kemenkop UKM), perkembangan perkoperasian meningkat antara 10-12\% setiap tahun. Pada tahun 2013, jumlah koperasi di Indonesia mencapai 203.701 unit. Jumlah tersebut meningkat signifikan dibanding tahun sebelumnya yang hanya mencapai 194.295 unit. Dari keseluruhan jumlah koperasi di Indonesia, Sumatera Utara merupakan provinsi dengan jumlah koperasi sejumlah 11.206 unit.

Indonesia menjadikan koperasi sebagai sumber kekuatan badan usaha dalam konteks kehidupan perekonomian, memang tidak terbatas pada nilai ekonomis nya semata. Kekuatan itu juga dapat bersumber dari faktor non-ekonomis yang menjadi faktor berpengaruh secara tidak langsung terhadap kegiatan ekonomi anggota masyarakat dan badan usaha koperasi. Karena koperasi selain memberikan kemanfaatan ekonomi juga mempunyai perhatian dan kepedulian terhadap aspek sosial seperti pendidikan, suasana sosial kemasyarakatan, lingkungan hidup, dan lainlain.

Kelangsungan hidup dan perkembangan koperasi sangat tergantung pada pengelolaannya. Pengelolaan yang baik akan membawa dampak positif terhadap koperasi sehingga koperasi mampu berkembang dengan pesat. Namun pengelolaan yang kurang baik terhadap koperasi yang ada justru akan membawa dampak yang buruk dalam koperasi tersebut dan secara tidak langsung pada perekonomian masyarakat setempat. Banyak daerah yang terus berproses dalam mengembangkan koperasi salah satunya adalah daerah Kisaran. 
Kota Kisaran sendiri menjadikan koperasi sebagai aset utama untuk meningkatkan pendapatan daerah dan mensejahterakan masyarakat sekitar. Maka dari itu, pemerintah kota kisaran tengah gencar membangun dan mengembangkan koperasi yang memiliki aset yang berkualitas di dalamnya dan tanpa disadari, begitu banyak potensi koperasi di kota Kisaran, mulai dari rentetan keanggotaan, jenis usaha hingga potensipotensi ekonomi lainnya.

Penelitian Melany, dkk (2013) dengan judul, Peran Koperasi Dalam Meningkatkan Perekonomian Masyarakat Nelayan. Berdasarkan analisis sistem yang dilakukan tergambar bahwa selama ini KSU Citra Nelayan baru dapat membantu anggota dalam menampung hasil tangkapan dan kemudian baru dipasarkan. Responden yang menjual hasil tangkapan ke koperasi hanya 50 persen, selebihnya menjual sendiri dan bahkan mengkonsumsi langsung hasil tangkapan. Meskipun demikian responden yang menyatakan nilai jual sesuai dengan harga pasar sebanyak 75 persen sedangkan yang menyatakan hasil diperoleh tidak sesuai dengan yang diharapkan sebesar 80 persen.

Penelitian Susila. (2014) dengan judul Strategi Kesuksesan BMT Maslahah Dalam Pengembangan Usshs dan Pemberdayaan Ekonomi Ummat menyatakan strategi koperasi BMT Maslahah untuk pengembangan lembaga mampu meningkatkan usaha koperasi BMT Maslahah guna mencapai tujuan pendirian koperasi. Peran koperasi BMT Maslahah dalam pemberdayaan ekonomi umat cukup signifikan, yaitu banyaknya pembiayaan koperasi ditujukan untuk masyarakat kecil dalam hal ini usaha mikro.

Penelitian tentang Analisis Perkembangan Koperasi Di Kabupaten Dairi ,Studi Kasus Koperasi Unit Desa dan Koperasi Pertanian Kecamatan Sidikalang, Kecamatan Siempat Nempu dan Kecamatan Siempat Nempu Hulu, Kabupaten Dairi, Provinsi Sumatera Utara oleh Nenny (2006) menyatakan hubungan faktor internal dan eksternal koperasi terhadap perkembangan koperasi secara statistik mempunyai hubungan yang signifikan (nyata).

Penelitian yang dilakukan oleh Mursidah, Hamzah, dan Sofyan (2013), diperoleh hasil penelitian bahwa analisis dengan metode shift share menunjukkan bahwa sektor yang mempunyai nilai kompetitif adalah 
sektor pertambangan dan penggalian, industri pengolahan, listrik, gas dan air bersih, konstruksi dan perdagangan, hotel dan restoran serta sektor jasa (nilai $r_{i j}>r_{i n}$ ) dan menunjukkan pergeseran yang positif terhadap semua sektor ditunjukkan dengan nilai Dij yang positif. Berdasarkan hasil analisis tersebut dapat disimpulkan bahwa Kabupaten Aceh Besar sesuai menjadi kawasan andalan dengan kriteria cepat tumbuh dan cepat maju, mempunyai interaksi wilayah dengan wilayah sekitarnya dan terdapat sektor yang mempunyai nilai ekspor dan menjadi sektor unggulan. Implikasi kebijakan yang diharapkan adalah intensifikasi dan ekstensifikasi sektor pertanian, dan menjadikan Kabupaten Aceh Besar sebagai wilayah pengembangan industri dan perdagangan.

Penelitian Mangun, M. (2007) dengan judul Analisis Potensi Ekonomi Kabupaten dan Kota di Provinsi Sulawesi Tengah hasil analisis Shift Share menunjukkan bahwa tidak terdapat sektor yang mempunyai keunggulan kompetitif di semua Kabupaten/Kota di Provinsi Sulawesi Tengah, tetapi memiliki spesialisasi. Sektor Listrik, Gas, Air Bersih dan sektor Perdagangan, Hotel, Restoran dan sektor jasa-jasa mempunyai spesialisasi di 6 Kabupaten/Kota; Sektor Industri Pengolahan; Pengangkutan Komunikasi dan Sektor Keuangan,Persewaan dan Jasa Perusahaan 5 Kabupaten/Kota; Sektor Pertanian; sektor Pertambangan Penggalian 4 Kabupaten Kota.

\section{METODE PENELITIAN}

Penelitian ini dilakukan pada dua kecamatan di Kota Kisaran, Provinsi Sumatera Utara yaitu kecamatan Kisaran Barat dan kecamatan Kisaran Timur. Penelitian dilaksanakan bulan Juni sampai bulan September tahun 2016. Lokasi penelitian ditentukan secara Purposive, berdasarkan pertimbangan bahwa, kecamatan Kisaran Barat dan kecamatan Kisaran Timur merupakan kecamatan yang berada di Kabupaten Asahan, Provinsi Sumatera Utara dengan jumlah anggota koperasi terbesar.

Populasi penelitian ini adalah pemuda yang ada di kota Kisaran, Kabupaten Asahan, provinsi Sumatera Utara. Dalam pengambilan sampel, pemuda tersebut objek dari sampel penelitian sebab menghindari penilaian terhadap diri sendiri sehingga menjadi tidak objektif. Perhitungan sampel mengunakan rumus perhitungan Frank Lynch: 


$$
\mathrm{n}=\frac{N \cdot Z^{2} \cdot P(1-P)}{N d^{2}+z^{2} P(1-P)}
$$

Menurut Badan Pusat Statistik tahun 2015, jumlah penduduk menurut kelompok umur 15-29 tahun berjumlah 35.162 jiwa. Berdasarkan rumus Frank Lynch maka ditetapkan sampel penelitian adalah sebanyak 96 orang.

Berdasarkan jenis masalah yang diteliti, teknik penelitian yang digunakan pada penelitian ini adalah deksriptif kuantitatif. Sumber data penelitian diperoleh secara langsung dari sumbernya yaitu melalui kuisioner berdasarkan daftar pertanyaan dalam beberapa item dan pilihan yang akan dijawab oleh responden. Selain itu ada pula data sekunder yang diperoleh dari dinas Koperasi Perindustrian dan Perdagangan kabupaten Asahan, dan Badan Pusat Statistik (BPS) kabupaten Asahan.

Metode analisis yang digunakan dalam penelitian ini adalah Analisis Deskriptif Persentase. Metode ini digunakan untuk mengkaji variabel yang ada pada penelitian yaitu peran pemuda $(X)$ dan pengembangan koperasi di kota Kisaran (Y). Dan Analisis Shift Share digunakan untuk menganalisis dan mengetahui pergeseran dan peranan ekonomi di daerah. Metode ini dipakai untuk mengamati struktur perekonomian dan pergeserannya dengan cara menekankan pertumbuhan sektor di daerah yang dibandingkan dengan sektor yang sama pada tingkat daerah yang lebih tinggi atau nasional. Shift Share merupakan teknik yang sangat berguna dalam menganalisis perubahan struktur ekonomi daerah dibandingkan dengan perekonomian nasional. Analisis ini memberikan data tentang kinerja perekonomian dalam 3 bidang yang berhubungan satu dengan yang lain yaitu: Komponen Provincial Share, Pergeseran proporsional (Proportional Shift), Pergeseran differensial (Differential Shift).

\section{HASIL DAN PEMBAHASAN}

Penelitian dilakukan secara purposive di Kisaran Barat dan Kisaran Timur dengan mengunjungi 16 koperasi diantaranya: CU April 76, Kopkar PT BSP, KSP Dana Mutiara, KPRI Al-Ikhlas Depag, KPRI Mutiara, KSU Sadakarsa, KSP Kazero, KSP Sri Padu, KSP Bona Mandiri Jaya, KPRI 
Handayani, Primkoppol, KPRI Mekar, CU Harapan Jaya, BMT Muslimat Alwasliyah, KSP Niaga Mitra, serta KJKS Selasih.

Tabel 1. PDRB kabupaten Asahan atas dasar harga konstan (2000) tahun 2010 dan 2015

\begin{tabular}{|c|c|c|c|c|c|}
\hline $\mathrm{NO}$ & \multirow{2}{*}{$\begin{array}{c}\text { Sektor } \\
2010\end{array}$} & \multicolumn{2}{|c|}{ Sumatera Utara } & \multicolumn{2}{|c|}{ Asahan } \\
\hline & & 2010 & 2015 & 2010 & 2015 \\
\hline & & $E_{N, i, t-n}$ & $E_{N, i, t}$ & $E_{r, i, t-n}$ & $E_{r, i, t}$ \\
\hline 1 & Pertanian & 28040,20 & 110123,24 & 1942,01 & 8993,39 \\
\hline 2 & Pertambangan & & & & \\
\hline & penggalian & 1400,65 & 5829,94 & 1420,456 & 42705,2 \\
\hline 3 & Industri & 26015,21 & 85968,40 & 1727,32 & 4466,6391 \\
\hline 4 & Listrik, Gas ,dan Air & & & & \\
\hline & minum & 872,14 & 963,27 & 66,24 & 32,8385 \\
\hline 5 & Bangunan & 8066,15 & 54248,91 & 141,73 & 1330,18 \\
\hline 6 & Perdagangan, Hotel, dan & & & & \\
\hline & Restoran & 21919,34 & 86904,33 & 855,55 & 3699,92 \\
\hline 7 & Pengangkutan & & & & \\
\hline & Komunikasi & 11633,90 & 31210,95 & 203,724 & 824,45 \\
\hline 8 & $\begin{array}{lr}\text { Keuangan, Usaha } \\
\text { Persewaan dan Jasa }\end{array}$ & & & & \\
\hline & Perusahaan & 8795,14 & 35914,12 & 141,676 & 655,71 \\
\hline 9 & Jasa-Jasa & 11976,16 & 15150,65 & 297,372 & 411,665 \\
\hline & Jumlah & 118718,89 & 426313,8 & 6796,078 & 63119,993 \\
\hline
\end{tabular}

Hasil uji validitas dan reliabilitas variabel peran pemuda sebagai Agent of Change, Agent of Development, dan Agent of Modernization

Uji validitas dilakukan dengan membandingkan nilai correlated item - total correlation pada setiap butir pertanyaan terhadap nilai $r$ variabel. Sunyoto (2009: 72) menyatakan jika nilai correlated item -total correlation rhitung > nilai rable dan nilainya positif, maka butir pertanyaan pada setiap variable penelitian dinyatakan valid. Nilai rtabel pada $\mathrm{df}=\mathrm{n}-2=96-2=94$ dan $\alpha=$ 0,05 adalah 0,168 Tidak ada satupun nilai correlated item - total correlation di bawah 0,168 , maka seluruh butir pertanyaan valid.

Sunyoto (2009) menyatakan bahwa butir pertanyaan disebut reliabel atau handal jika jawaban seseorang terhadap pertanyaan bersifat konsisten dari waktu ke waktu. Pengukuran reliabilitasnya menggunakan uji statistik QE Journal |Vol.07 - N o. 01 M arch 2018 - 63 
Cronbach Alpha. Menurut Sunyoto (2009: 68) suatu konstruk dikatakan reliabel jika memberikan nilai Cronbach Alpha $>0,60$. Seluruh Cronbach Alpha di setiap butir pertanyaan bernilai di atas 0,60 , maka seluruh butir pertanyaan reliable.

Analisis Deskriptif Persentase Variabel peran pemuda sebagai Agent of Change, Agent of Development, dan Agent of Modernization.

Tabel 2. Peran pemuda sebagai Agent of Change

\begin{tabular}{|c|c|c|c|c|c|}
\hline \multirow{2}{*}{ Pernyataan } & \multicolumn{5}{|c|}{ Frekuensi } \\
\hline & SS & $\mathrm{S}$ & RR & TS & STS \\
\hline $\mathrm{C} 1$ & $32,29 \%$ & $64,58 \%$ & $02,08 \%$ & $01,04 \%$ & $00,00 \%$ \\
\hline $\mathrm{C} 2$ & $23,96 \%$ & $62,50 \%$ & $09,38 \%$ & $04,17 \%$ & $00,00 \%$ \\
\hline $\mathrm{C} 3$ & $30,21 \%$ & $59,38 \%$ & $10,42 \%$ & $00,00 \%$ & $00,00 \%$ \\
\hline $\mathrm{C} 4$ & $33,33 \%$ & $57,29 \%$ & $08,33 \%$ & $01,04 \%$ & $00,00 \%$ \\
\hline $\mathrm{C} 5$ & $40,63 \%$ & $55,21 \%$ & $04,17 \%$ & $00,00 \%$ & $00,00 \%$ \\
\hline
\end{tabular}

Sumber: Hasil Pengolahan Data Primer

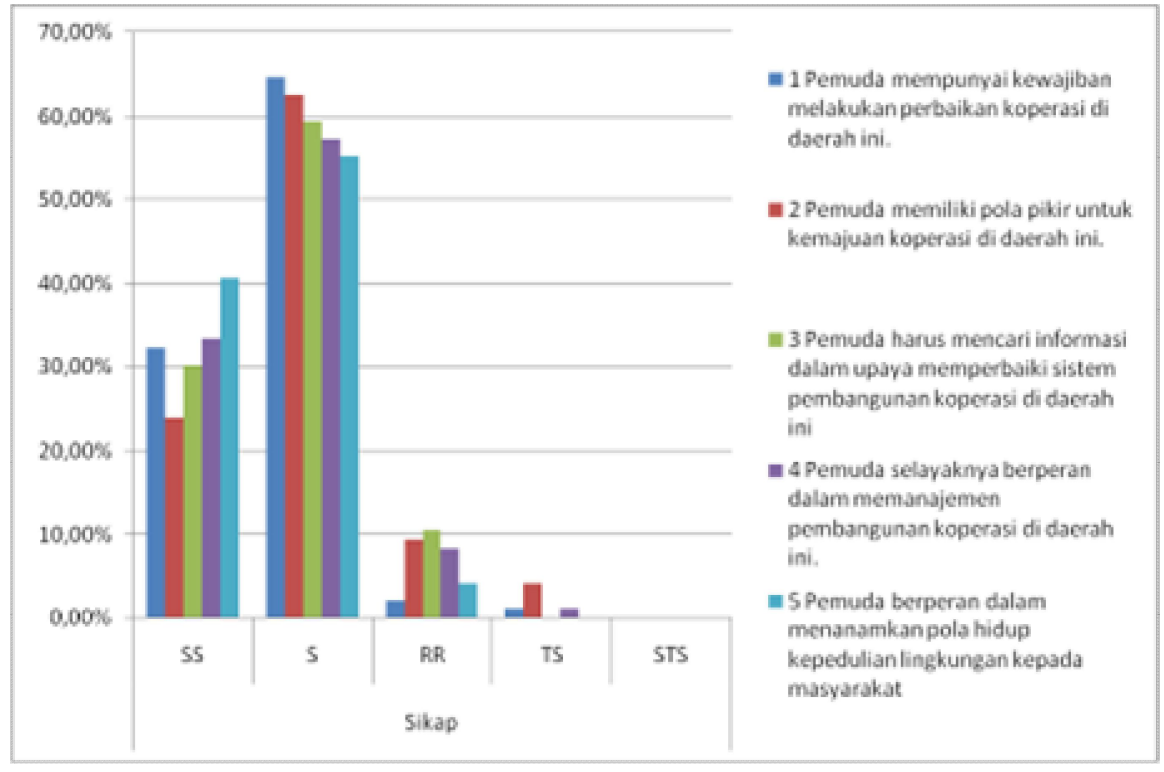

Gambar 1 Peran pemuda sebagai Agent of Change 
Tabel 3. Peran pemuda sebagai Agent of Development

\begin{tabular}{cccccc}
\hline \multirow{2}{*}{ Pernyataan } & \multicolumn{5}{c}{ Frekuensi } \\
\cline { 2 - 6 } & SS & S & RR & TS & STS \\
\hline D1 & $27,08 \%$ & $68,75 \%$ & $02,08 \%$ & $02,08 \%$ & $00,00 \%$ \\
D2 & $23,96 \%$ & $58,33 \%$ & $15,63 \%$ & $02,08 \%$ & $00,00 \%$ \\
D3 & $31,25 \%$ & $61,46 \%$ & $07,29 \%$ & $00,00 \%$ & $00,00 \%$ \\
D4 & $31,25 \%$ & $53,13 \%$ & $12,50 \%$ & $03,13 \%$ & $00,00 \%$ \\
D5 & $28,13 \%$ & $59,38 \%$ & $07,29 \%$ & $04,17 \%$ & $01,04 \%$ \\
\hline
\end{tabular}

Sumber: Hasil Pengolahan Data Primer

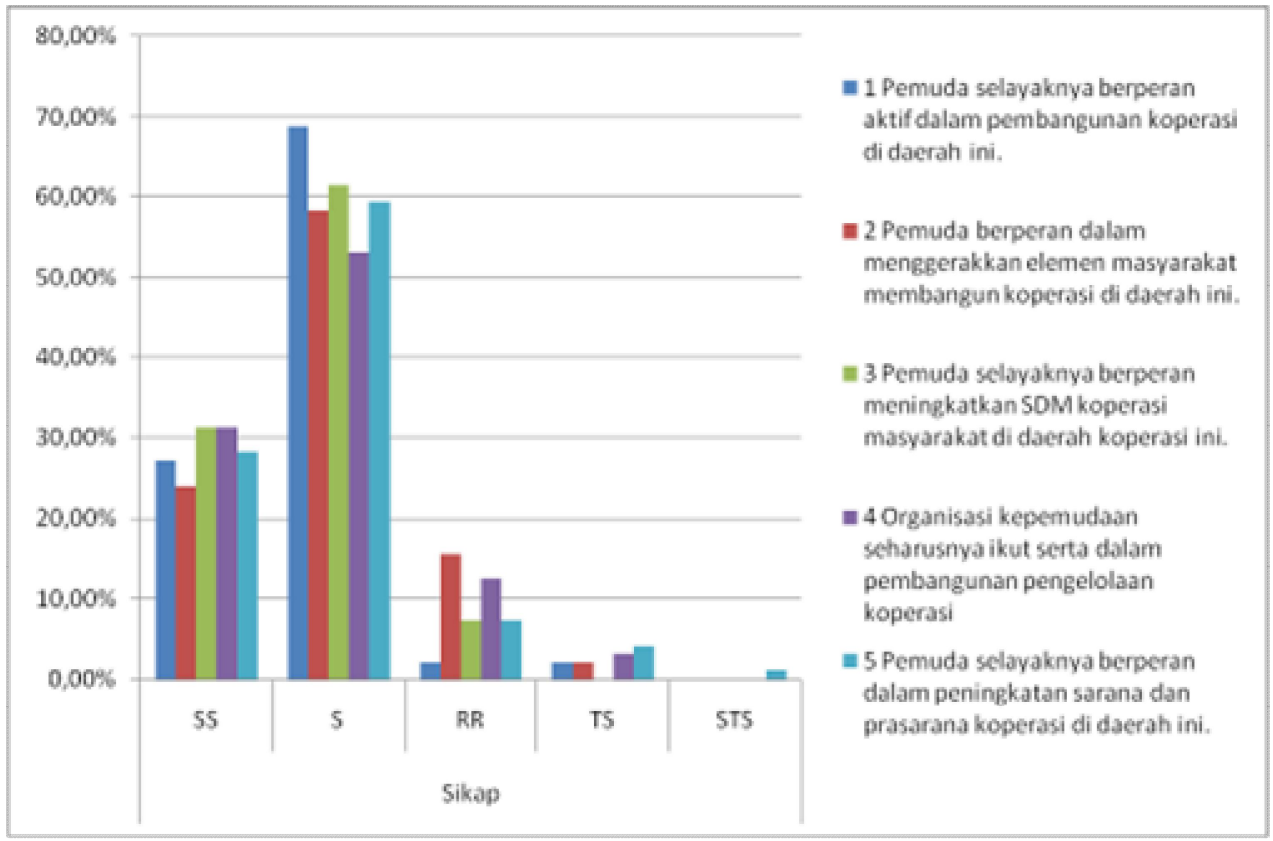

Grafik 2. Peran pemuda sebagai Agent of Development

Terkait dengan hal tersebut pemuda sebagai agen perubahan (Agent of Change) dan agen pembangunan (Agent of Development), dan agen modernisasi (Agent of Modernization) agar hal ini terealisasi dapat dilakukan melalui koperasi, ormas, sarana dan arena belajar, bereksperimen dan berlatih menjadi agen perubahan (Agent of Change) dan agen pembangunan (Agent of Development), dan agen modrenisasi (Agent of Modernization). Sehingga dengan demikian, para pemuda sebagai generasi penerus harus aktif dan mau terlibat dalam organisasi kepemudaan, organisasi profesi, 
organisasi fungsional, hal ini wadah yang tepat untuk membangun kepeloporan dan kepemimpinan yang diharapkan.

Tabel 4. Peran pemuda sebagai Agent of Modernization

\begin{tabular}{cccccc}
\hline \multirow{2}{*}{ Pernyataan } & \multicolumn{5}{c}{ Frekuensi } \\
\cline { 2 - 6 } & SS & S & RR & TS & STS \\
\hline M1 & $17,71 \%$ & $64,58 \%$ & $13,54 \%$ & $04,17 \%$ & $00,00 \%$ \\
M2 & $23,96 \%$ & $67,71 \%$ & $05,21 \%$ & $01,04 \%$ & $02,08 \%$ \\
M3 & $27,08 \%$ & $68,75 \%$ & $03,13 \%$ & $01,04 \%$ & $00,00 \%$ \\
M4 & $16,67 \%$ & $60,42 \%$ & $22,92 \%$ & $00,00 \%$ & $00,00 \%$ \\
M5 & $25,00 \%$ & $66,67 \%$ & $08,33 \%$ & $00,00 \%$ & $00,00 \%$ \\
\hline
\end{tabular}

Sumber: Hasil Pengolahan Data Primer

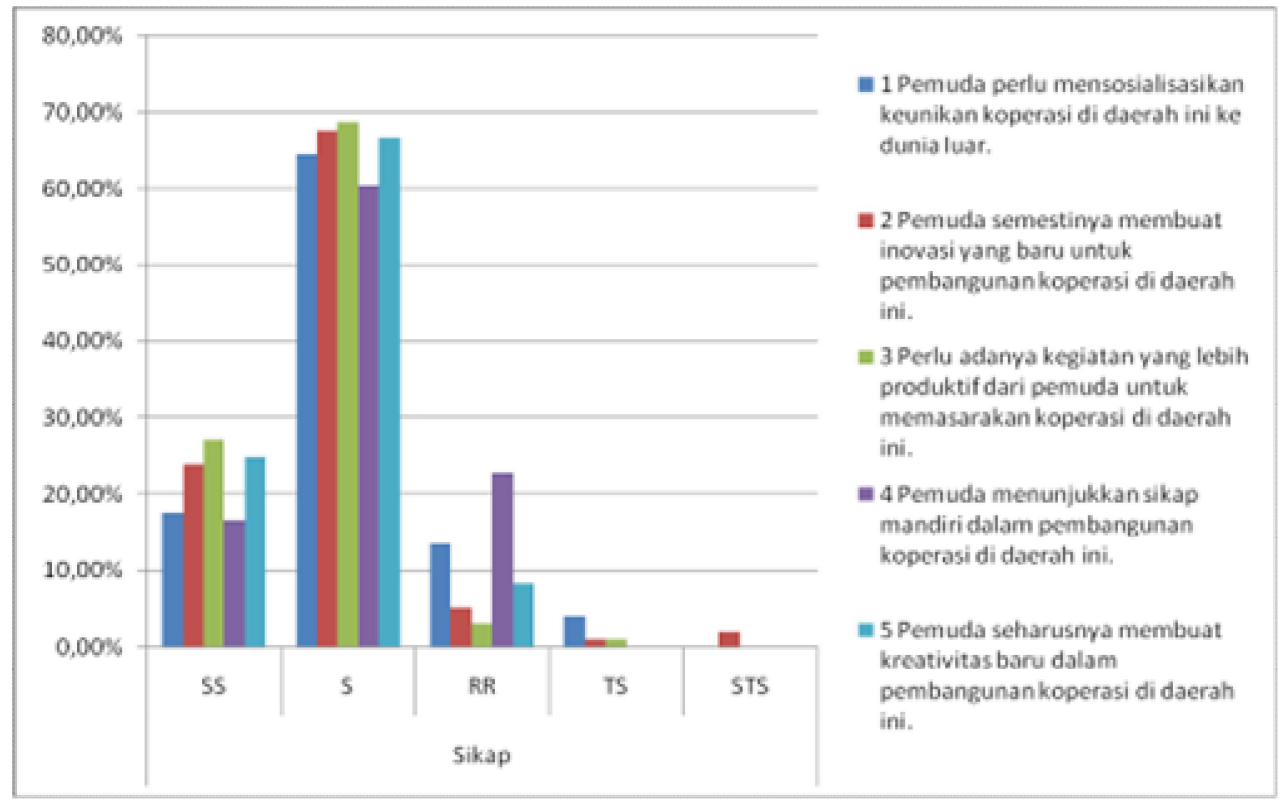

Grafik 3. Peran pemuda sebagai Agent of Modernization

\section{Variabel pembangunan Koperasi}

Pembangunan koperasi memerlukan pemuda untuk melakukan perubahan kearah yang lebih baik. Pembangunan dan pemuda merupakan dua aspek yang harus saling mengisi agar pembangunan suatu daerah menjadi lebih cepat, maju dan berkembang bersama masyarakat. 
Tabel 5. Pembangunan Koperasi

\begin{tabular}{cccccc}
\hline \multirow{2}{*}{ Pernyataan } & \multicolumn{5}{c}{ Frekuensi } \\
\cline { 2 - 6 } & SS & S & RR & TS & STS \\
\hline P1 & $25,00 \%$ & $60,42 \%$ & $11,46 \%$ & $02,08 \%$ & $01,04 \%$ \\
P2 & $28,13 \%$ & $65,63 \%$ & $03,13 \%$ & $02,08 \%$ & $01,04 \%$ \\
P3 & $28,13 \%$ & $64,58 \%$ & $04,17 \%$ & $00,00 \%$ & $03,13 \%$ \\
P4 & $32,29 \%$ & $58,33 \%$ & $07,29 \%$ & $02,08 \%$ & $00,00 \%$ \\
P5 & $32,29 \%$ & $58,33 \%$ & $07,29 \%$ & $01,04 \%$ & $01,04 \%$ \\
\hline
\end{tabular}

Sumber: Hasil Pengolahan Data Primer

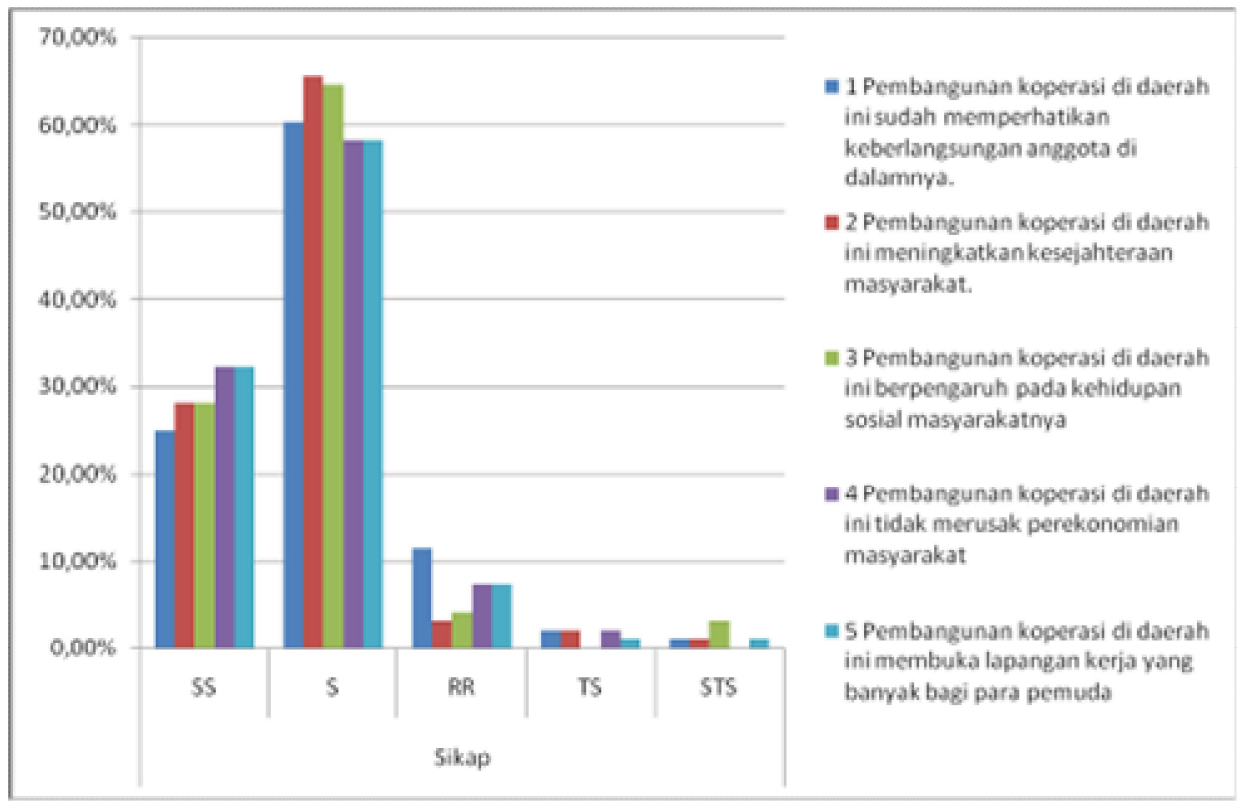

Gambar 4. Pembangunan Koperasi

Hasil Analisis Shift Share peran pemuda dalam pengembangan koperasi di kota Kisaran menggunakan data sektor Keuangan, Usaha Persewaan dan Jasa Perusahaan.

Koperasi dalam penelitian ini termasuk ke dalam sub sektor dari sektor Keuangan, Usaha Persewaan dan Jasa Perusahaan sebagaimana yang tertera dalam Klasifikasi Baku Lapangan Usaha Indonesia. 
Tabel 6. Analisis Shift Share

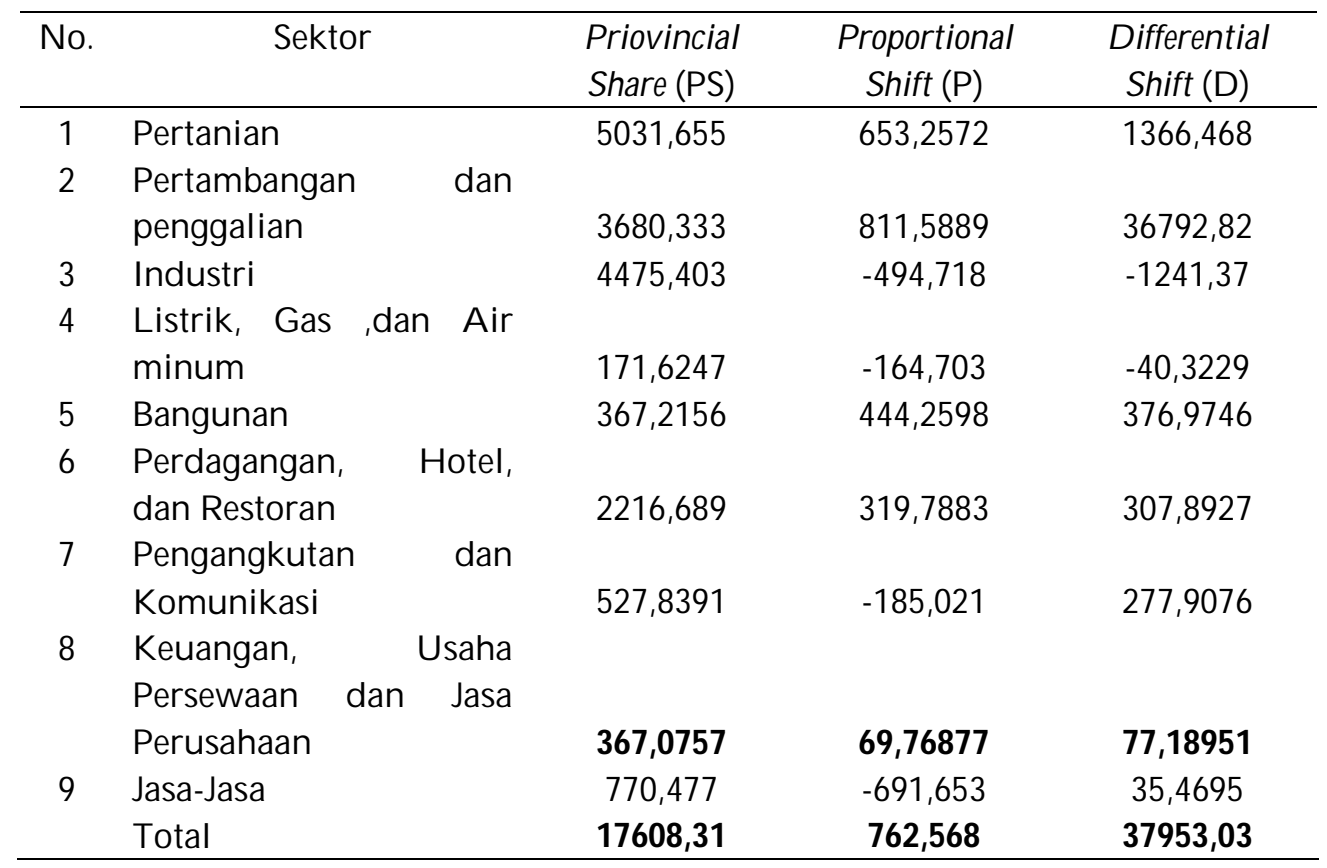

Nilai Provincial Share sub sub sektor koperasi (keuangan, usaha persewaan dan jasa perusahaan) lebih besar dari sektor listrik gas dan air minum tetapi lebih kecil dari sektor pertanian, pertambangan dan penggalian Industri, bangunan, perdagangan, hotel, dan restoran, pengangkutan dan komunikasi, serta jasa-jasa yang berarti sektor keuangan, usaha persewaan dan jasa perusahaan pertumbuhannya lebih cepat dibandingkan dengan sektor listrik gas dan air minum di provinsi Sumatera Utara. Artinya, kebijakan pemerintah berdampak pada pertumbuhan sub sektor keuangan, usaha persewaan dan jasa perusahaan, di mana sebagai sektor ekonomi penting, koperasi mendapatkan perhatian serius dari pemerintah, dengan dikeluarkannya Undang-undang Tahun 2012 No 17 tentang perkoperasian adalah sebagai dasar pijakan penyelenggaraan koperasi. Tujuan penyelenggaraan koperasi menurut undang-undang tersebut adalah meningkatkan kesejahteraan Anggota pada khususnya dan masyarakat pada umumnya, sekaligus sebagai bagian yang tidak terpisahkan dari tatanan perekonomian nasional yang demokratis dan berkeadilan. 
Pemerintah Kabupaten Asahan menggalakkan koperasi kota kisaran dengan: a) program pengembangan pemasaran koperasi, meliputi, peningkatan pemanfaatan teknologi informasi dalam pemasaran koperasi, pengembangan jaringan kerjasama promosi koperasi, pelaksanaan promosi produk koperasi di dalam dan di luar negeri, b) program pengembangan koperasi, meliputi, peningkatan pembangunan sarana dan perasarana koperasi, c. program pengembangan kemitraan, meliputi pengembangan SDM. Peningkatkan peran serta masyarakat dalam pengembangan kemitraan koperasi.

Pertumbuhan koperasi tidak senantiasa semulus apa yang diharapkan dan dibayangkan. Banyak permasalahan dan kendala yang dihadapi dalam setiap perkembangannya. Dalam menghadapi kesulitan koperasi seperti akses permodalan, keterbatasan informasi dan pasar, minim manajerial, gagap teknologi dapat diatasi dengan cara: 1) Mengeluarkan kebijakan guna mendorong percepatan pemberdayaan koperasi secara terarah dan bertahap. Kebijakan tersebut meliputi aspek-aspek kelembagaan, permodalan, kemampuan teknologi, kualitas SDM, pemasaran, jaringan usaha, menciptakan iklim yang kondusif, dan bertahap dimulai skema hibah untuk peningkatan keterampilan usaha. Secara terarah program ini dapat menyentuh segala aspek yang bertujuan dalam jangka pendek maupun dalam jangka panjang. 2) Memberikan bantuan modal kerja bagi koperasi. Dimana bantuan tersebut harus selektif, dimonitoring dan evaluasi. 3) Memberikan bantuan manajemen kepada koperasi atau pelatihan-pelatihan yang berkesinambungan. 4) Mensinergikan programprogram pembangunan dengan pemberdayaan koperasi. Sebagai contoh, program pembangunan lumbung pangan oleh Kementerian Pertanian. 5) Memberikan peranan yang lebih besar pada dinas koperasi ataupun Kementerian Negara Koperasi dalam pengembangan koperasi. 6) Modifikasi produk. Dengan memodifikasi produk-produk yang ada dikoperasi, akan meningkatkan selera masyarakat sehingga tertarik untuk mengkonsumsi produk dari koperasi tersebut.

Nilai Proportional Shift sub sektor koperasi 69,76877 relatif kecil dibanding dengan sektor sektor sektor pertanian, pertambangan dan penggalian, bangunan; perdagangan, hotel, dan restoran, tetapi berbeda dengan sektor industri yang nilainya -494,718; sektor listrik, gas, dan air minum yang nilainya -164,703; sektor pengangkutan dan komunikasi yang nilainya - 
185,021 dan sektor jasa-jasa yang nilainya -691,653. Artinya, sub sektor koperasi mendapatkan tambahan dari sektor-sektor yang negatif nilai Proportional Shift nya. Tambahan tersebut berasal dari sektor: (1) Sektor industri pengolahan, hal ini disebabkan karena pada saat krisis harga barang-barang melambung tinggi sehingga menyebabkan biaya produksi sektor tersebut meningkat karena sebagian bahan baku dan alat-alat modalnya berasal dari impor, (2) Sektor listrik gas dan air bersih, mengalami pertumbuhan yang negatif karena adanya krisis disebabkan penurunan kontribusi dari sektor pendukungnya selain itu terpengaruhnya tingkat penggunaan oleh rumah tangga dan produk dari sektor tersebut merupakan kebutuhan pokok bagi masyarakat dalam kehidupan sehari-hari, (3) Sektor pengangkutan dan komunikasi, hal ini disebabkan karena kebutuhan di sektor tidak begitu banyak dibanding sektor lain, serta (4) sektor jasa-jasa rendahnya dukungan kelembagaan pemerintah, kelembagaan yang ada lebih terfokus pada sektor yang memberikan kontribusi yang besar terhadap pembentukan PDRB kabupaten Asahan

Nilai Differential Shift sub sektor koperasi yaitu 77,18951 nilainya lebih kecil dari sektor pembangunan lainnya seperti sektor pertanian yang nilainya 1366,468, pertambangan dan penggalian yang nilainya 36792,82 , sektor bangunan yang nilainya 376,9746 , sektor perdagangan, hotel, dan restoran yang nilainya 307,8927, serta sektor pengangkutan dan komunikasi yang nilainya 277,9076 , hal ini berarti sub sektor koperasi memiliki daya saing yang lebih rendah dari sektor - sektor tersebut, di mana sektor pertambangan dan penggalian di kabupaten Asahan pertumbuhannya pesat. Rendahnya daya saing sub sektor koperasi di kabupaten Asahan karena rendahnya kebijakan dalam peraturan dan regulasi dari pemerintah, rendahnya koordinasi antar instansi yang terkait, rendahnya kesadaran dalam memelihara kemitraan koperasi.

Setiap pemuda harus diberdayakan agar berperan sebagai pelaku pembangunan ekonomi kerakyatan yang dinamis. Koperasi adalah wadah dan tatanan ekonomi dimana peranan pemuda sebagai pelaku utama menjadi ciri yang menonjol. Koperasi akan jaya kalau partisipasi dari seluruh anggotanya dilakukan secara profesional, aktif dan dinamis. Dengan pemuda yang berkualitas akan bisa dikembangkan koperasi yang dinamis, karena setiap anggotanya, baik secara sendiri maupun dalam QE Journal |Vol.07 - N o. 01 March 2018 - 70 
kesatuan kelompok koperasi, bisa memberi sumbangan terhadap kemajuan koperasinya. Setiap pemuda anggota koperasi mempunyai hak untuk ikut menentukan arahan melalui rapat-rapat anggota atau mekanisme lain dalam koperasinya. Koperasi adalah wujud nyata dari demokrasi ekonomi yang arahnya ditentukan oleh anggota, kekuatan geraknya ditentukan oleh anggota, dan hasil-hasilnya kelak, bisa dinikmati secara adil oleh anggotanya Lebih dari itu setiap anggota koperasi harus bisa menjadi contoh dalam mengembangkan suasana gotong royong saling membantu sesamanya. Setiap anggota dituntut untuk bisa memberikan sumbangan positif dalam bentuk usaha dengan kualitas yang tinggi. Upaya pemberdayaan pemuda dalam suasana yang serba sulit sekarang ini harus diberi makna dengan menyerap falsafah koperasi yaitu dengan mengajak sebanyak mungkin pemuda untuk segera bergabung dalam gerakan koperasi. Melalui koperasi setiap pemuda dibantu pemberdayaannya untuk mampu berusaha mengatasi masalah yang dihadapinya. Dengan dukungan itu bisa dihilangkan kesenjangan sosial yang sekaligus meredakan ketegangan sosial yang terjadi dilingkungan masyarakat.

\section{SIMPULAN}

Berdasarkan hasil penelitian dan pembahasan maka, dapat ditarik kesimpulan sebagai berikut:

1. Peran pemuda sebagai Agent of Change dengan indikator pemuda mempunyai kewajiban melakukan perbaikan koperasi memiliki peran yang paling banyak dilakukan pemuda yakni $64,58 \%$, sebagai Agent of Development dengan indikator pemuda berperan aktif dalam pembangunan koperasi memiliki peran paling banyak dilakukan pemuda yakni $68,75 \%$ dan sebagai Agent of Modernization dengan indikator adanya kegiatan produktif dari pemuda memasarkan koperasi di kota Kisaran memiliki peran paling banyak dilakukan pemuda yakni $68,75 \%$. Sehingga peran pemuda berpengaruh terhadap pengembangan koperasi di kota Kisaran.

2. Peran koperasi (sub bagian dari sektor keuangan, usaha persewaan dan jasa perusahaan) dalam pembangunan di kota Kisaran mempunyai nilai Provincial Share (PS) positif yang berarti bahwa banyaknya pertambahan PDRB kabupaten Asahan seandainya pertumbuhannya

QE Journal |Vol.07 - No. 01 March 2018 - 71 
sama dengan laju pertumbuhan PDRB Provinsi Sumatera Utara selama periode studi bernilai positif, dan Proportional Shift (P) positif yang berarti bahwa sub sektor koperasi di kabupaten Asahan memiliki pertumbuhan yang lebih cepat dibandingkan dengan sektor industri, listrik, gas dan air minum, pengangkutan dan komunikasi dan jasajasa, serta memiliki nilai Differential Shift (D) yang positif berarti bahwa sub sektor koperasi di kabupaten Asahan memiliki daya saing yang relatif tinggi dari sektor lainnya.

\section{Saran}

Adapun saran berdasarkan hasil penelitian ini sebagai berikut:

1. Pemerintah dan juga masyarakat termasuk pemuda di dalamnya harus memiliki kepedulian yang lebih besar untuk pembangunan koperasi di kota Kisaran.

2. Pemuda di kota Kisaran perlu mempertahankan dan meningkatkan peranannya sebagai Agent of Change dan Agent of Development, Agent of Modernization dalam meningkatkan pembangunan koperasi di kota Kisaran.

\section{DAFTAR PUSTAKA}

Abdullah, Taufik. 1974. Pemuda dan Perubahan Social. LP3ES: Jakarta

Ambarita, B. 2013. Generasi Kampus. Volume.6, No.2 :1

Arikunto, S. 2006. Prosedur Penelitian Suatu Pendekatan Praktik. Rineka Cipta : Jakarta

Caska. 2014. Dinamika Pembangunan Ekonomi dan Koperasi. UR Press: Pekanbaru

Erlina. 2008. Metode Penelitian Bisnis: untuk Akuntansi dan Manajemen. Edisi ke dua cetakan pertama.USU Press: Medan

Ghozali, Imam. 2005. Aplikasi Analisis Multivariate dengan program SPSS. Edisi Ketiga. Badan Penerbit Universitas Diponegoro: Semarang.

Kuncoro, Mudrajad. 2012. Perencanaan Daerah, Bagaimana Membangun Ekonomi Lokal, Kota, dan Kawasan. Salemba Empat: Jakarta 
Mangun M. 2007. Analisis Potensi Ekonomi Kabupaten dan Kota di Propinsi Sulawesi Tengah. [Tesis]. Semarang : Universitas Diponegoro, Program Pasca Sarjana

Melani, dkk. 2013. Peran Koperasi dalam Meningkatkan Perekonomian Masyarakat Nelayan. Tanjung Pinang

Mulyono, Rohmad. 2011. Mengartikulasi Pendidikan Nilai. Alfabeta: Bandung Mursidah, Hamzah A, Sofyan. 2013. Analisis Pengembangan Kawasan Andalan di Kabupaten Aceh Besar. Vol.1, No.1 : 43

Nababan, Nenny. 2006. Analisis Perkembangan Koperasi di Kabupaten Dairi. Univeritas Sumatera Utara, Program Agribisnis: Medan

Nasution, Muslimin. 1987. Strategi menuju Keswadayaan Koperasi. Badan Penelitian dan Pengembangan Koperasi : Jakarta

Nana, Sudjana. 2001. Metode Statistika, Edisi Revisi, Cet. 6. Tarsito: Bandung Rangkuty, Freddy. 2009. Analisis SWOT Teknik Membedah Kasus Bisnis, Reorientasi Konsep Perencanaan Strategis Menghadapi Abad 21. Gramedia Pustaka Utama: Jakarta

Sitio, Arifin. 2001. Teori dan Praktik Koperasi. Erlangga: Jakarta

Sirojuzilam, Kasyful. 2010. Pembangunan Wilayah, Perencanaan, dan Ekonomi.USU Press: Medan

Sugiyono. 2005. Metode Penelitian Bisnis, Cetakan Kesembilan, Penerbit CV. Alfabeta: Bandung.

Susila, A. Agus. 2014. Strategi Kesuksesan Koperasi BMT Maslahah dalam Pengembangan Usaha dan Pemberdayaan Ekonomi Ummat. Program Pascasarjana Uin Sunan Kalijaga: Yogyakarta

Tarigan, Robinson. 2005. Ekonomi Regional. PT Bumi Aksara: Jakarta.

Undang-Undang Republik Indonesia Nomor 17 Tahun 2012

Undang-Undang Republik Indonesia Nomor 40 Tahun 2009

Widyanto, B. 2010. Pemuda dalam Perubahan Sosial. UN Sanata Darma: Yogyakarta 
Yitnosumarto, Suntoyo. 2009. Dasar-Dasar Statistika Terapan dalam Bidang Agrokompleks, Teknologi, dan Sosial. Raja Grafindo Persada: Jakarta 